\title{
Planting dates and morphology and growth of four sweet potato clones in Puerto Rico'
}

\author{
Franklin W. Martin ${ }^{2}$
}

\begin{abstract}
Four clones of sweet potato were planted monthly in 1984, and 11 morphological and growth characteristics were measured. Clones differed with respect to all characteristics, and significant differences were found among months in all but one characteristic. The 11 characteristics could be classified as modal, bimodal, irregular or complex with respect to monthly distribution. Several of the characteristics regressed on months by linear, quadratic or cubic regression. Others were not clearly related and differences are believed to be caused by cultural factors that may have varied. Four external variables affecting sweet potatoes, (day length, rainfall, temperature and solar radiation) could have accounted for many of the observed differences among months.
\end{abstract}

\section{RESUMEN}

Época de siembra, morfología y crecimiento de cuatro clones de batata (Ipomoea batatas L. Lam.) en Puerto Rico

Cuatro clones de batata se sembraron mensualmente en 1984 y se midieron 11 características morfológicas y de crecimiento. Los clones mostraron diferencias en todas las características; se encontraron diferencias significativas entre meses en todas las características estudiadas excepto una. Las 11 características se clasificaron como modal, bimodal, irregular - compleja en distribución sobre meses. Varias de las caraterísticas mostraron regresión linear, cuadrática o cúbica con el mes de siembra. Otras no estuvieron tan claramente relacionadas con la estación; parece que las afectaron unos factores culturales que no siempre se pudieron controlar. Cuatro variables externas que afectan la batata: largo del día, lluvias, temperaturas y radiación solar, podrían haber sido las causas principales de muchas de las diferencias observadas entre algunes meses.

\section{INTRODUCTION}

In the hot tropics it is possible to plant sweet potatoes at any time of the year and thus harvest throughout the year. Nevertheless, there are usually practical constraints to year round production, including the availability of water. Sweet potatoes are photoperiod-sensitive and the majority will flower during the short days corresponding to the temperate winter season (6). Likewise, yields appear to depend on season. Most

' Manuseript submitted to Editorial Board 17 February 1987.

${ }^{2}$ Research Horticulturist, United States Department of Agriculture, Tropical Agricultural Researeh Station, Mayagiiez, Puerto Rico. 
cultivars produce best when planted from September to November in Puerto Rico, and mature in February-Mareh (1). Thus, short days apparently stimulate storage root growth. According to McDavid and Alamu (6) long days increase branch length, reduce branch number, promote leaf expansion, and delay senescence. However, some cultivars, such as the US-bred "Gem," appeared to be day neutral,

Rainfall and irrigation can also affect the growth of sweet potato. Excessive water leads to the production of abundant vines and poor yields. Haynes et al. (3) suggested that the best environment for sweet potatoes in the tropics would be one with very frequent rains at planting and during establishment, and abundant sunshine during the period of growth of the storage roots. Both excess water and lack of oxygen in the soil are believed to be associated with poor storage root production. Thus, well-drained soil is preferred.

During 5 successive years, Gollifer (2) found vine and root yields to be negatively correlated. Smallest yields occurred after periods of heavy rains when vines were growing vigorously. There was a positive correlation of vine weight with rainfall, and of solar radiation with storage root production. He also found a negative correlation between root weight and rainfall.

Mannan and Rashid (4) in Pakistan found sweet potatoes to yield best from October to March when temperatures were moderate, skies were clear, and rainfall was low to moderate. Poor production was obtained from April to September when temperatures were high, the sky cloudy, and rainfall very frequent.

The present study was done to investigate the effects of planting dates on morphology and growth characteristics of sweet potato at one location in Puerto Rico. Effects on yield will be reported in a separate manuscript.

\section{MATERIALS AND METHODS}

The experiment was conducted in 1984 in an Oxisol (Tropeptic Haplorthox, clayey, kaolinitic, isohyperthermic) at the Isabela experiment farm of the Tropical Agriculture Research Station (TARS), ARS, USDA. The experimental variables were 12 monthly planting dates and four sweet potato clones. The general characteristics of the experimental site were as follows:

Location

Latitude

Longitude

Temperature range

Elevation

Annual rainfall
Northwestern P. R. $18^{\circ} 30^{\prime} \mathrm{N}$

$67^{\circ} \mathrm{W}$

18.8 to $29.4^{\circ} \mathrm{C}$

$128 \mathrm{~m}$

$1,675 \mathrm{~mm}$ 


$\begin{array}{ll}\text { Soil } & \text { Oxisol (Coto) } \\ \text { Organic matter content } & 3 \% \\ \text { Exchange capacity (meg. } / 100 \mathrm{~g} \text { soil) } & 23 \\ \text { pH } & 5.1\end{array}$

Four sweet potato clones were used. "Miguela" is a local white-fleshed medium sweet cultivar recommended in Puerto Rico. "Gem" is a dessert type that was developed in the United States but is very well adapted to Puerto Rico. SPT-8 and SPV-46 are selected lines of the Tropical Agriculture Research Station, Mayagüez, Puerto Rico. Sweet potatoes were planted monthly for 12 months in randomized complete blocks with 4 replications. Cuttings were spaced $30 \mathrm{~cm}$ apart in rows $100 \mathrm{~cm}$ apart. The fields were fertilized at the rate of $950 \mathrm{~kg} / \mathrm{ha}$ with 6-6-12 mineral fertilizer placed in holes in the soil between plants 2 weeks after planting. Weeds were suppressed initially by $19 \mathrm{~L} / \mathrm{ha}$ of Amiben herbicide (contains chlorambem, 3-amino-2,5-dichlorobenzoic acid) applied after planting and followed by light irrigation. Later, weeds were controlled by light hoeing as necessary.

Day lengths were shortest December 21 (about 11 hours) and longest June 21 (about 13 hours). The rainy season corresponded to appproximately June to December. Driest months were January-March. The plantings were irrigated as needed during dry weather. The hottest season was July-October, and the coolest December-March.

Percentage survival of cuttings was noted 2 and 4 weeks after planting. Table 1 gives the characteristics thought to vary with season. When plantings were 2 months old, the leaf type, length of internode, length

TABLE 1.-Morphological and grouth characteristics observed of sueet potato in 12 monthly plantings

\begin{tabular}{|c|c|c|c|c|}
\hline No. & Characteristics & $\begin{array}{l}\text { Age of } \\
\text { planting }\end{array}$ & Scale & Explanation \\
\hline 1 & Survival of euttings & 2 weeks & $\%$ & Counted and calculated \\
\hline 2 & Survival of euttings & 4 weeks & $\%$ & Counted and calculated \\
\hline 3 & Leaf lobing & 2 months & $1-5$ & $1=$ no lobing, $5=$ extreme lobing \\
\hline 4 & Length of internode & 2 months & $\mathrm{cm}$ & Average of 10 measurements \\
\hline 5 & Length of vine & 2 months & $\mathrm{cm}$ & Average of 10 measurements \\
\hline 6 & Width of vines & 2 months & $\mathrm{cm}$ & $\begin{array}{l}\text { Average width of plants, } \\
\text { disregarding occasional vines }\end{array}$ \\
\hline 7 & Degree of flowering & 2 months & $0-5$ & 0 , none, to 5 , capsules present \\
\hline 8 & Degree of flowering & 4 months & $0-5$ & \\
\hline$\theta$ & Rooting of runners & 4 months & 1-5 & $\begin{array}{c}1=\text { runners do not root at nodes } \\
5=\text { all runners root at all nodes }\end{array}$ \\
\hline 10 & $\begin{array}{l}\text { Production of storage } \\
\text { roots, rumers }\end{array}$ & 4 months & $1-9$ & $\begin{array}{l}1=\text { none, } 9 \text { - all nodes produce } \\
\text { storage roots }\end{array}$ \\
\hline 11 & Vine weight & 4 months & $\mathrm{kg}$ & $\begin{array}{l}\text { Fresh weight of all foliage at time } \\
\text { of harvest }\end{array}$ \\
\hline
\end{tabular}


TABLE 2. Summary of differences in months and clones found by analyses of variamce for 11 characteriatics, 4 clones, and 12 months of planting

\begin{tabular}{|c|c|c|c|c|c|c|}
\hline \multirow[b]{2}{*}{ No. } & \multirow[b]{2}{*}{ Characteristic } & \multicolumn{4}{|c|}{ Fvalue } & \multirow[b]{2}{*}{ Distribution of months } \\
\hline & & Months & Clones & Interaction & Blocks & \\
\hline 1 & Survival, 2 weeks & $9.80^{x x x}$ & $6.52^{2 x \times x}$ & $2.71^{\mathrm{xxx}}$ & .88 & Irregular \\
\hline 2 & Survival, 4 weeks & $13.20^{\mathrm{xxx}}$ & $9.84^{\times \times x}$ & $2.99^{\mathrm{x} \times \mathrm{x}}$ & $1.53^{*}$ & Irregular \\
\hline 3 & Leaf lobing & 0.00 & $144.00^{x \times x}$ & 0.00 & 0.00 & No monthly difference \\
\hline 4 & Internode length & $5.98^{\mathrm{xxx}}$ & 185.13 & $1.65^{*}$ & 0.74 & Modal \\
\hline 5 & Vine length & $20.26^{\mathrm{xxx}}$ & $8.33^{3 \times x}$ & .81 & .31 & Modal \\
\hline 6 & Plant width & $46.59^{\mathrm{xxx}}$ & $14.96^{\mathrm{xxx}}$ & $1.65^{*}$ & .71 & Modal \\
\hline 7 & Flowering, 2 months & $22.68^{\mathrm{xxx}}$ & $78.14^{\mathrm{xxx}}$ & $11.83^{\mathrm{xxx}}$ & .81 & Modal \\
\hline 8 & Flowering, 4 months & $12.95^{\mathrm{xxx}}$ & $56.96^{\mathrm{xxx}}$ & $9.26 \times x \times$ & .53 & Complex \\
\hline 9 & Rooting of rumner & $31.83^{\times x x}$ & $5.95 \times x$ & $3.97 \mathrm{xx}$ & 1.06 & Bimodal \\
\hline 10 & Production of storage roots, stem & 25.87 xox & $41.62^{x 0 x}$ & $1.93^{x}$ & 1.22 & Minimum monthly difference \\
\hline 11 & Weight of vines & $3.05^{\mathrm{xx}}$ & $4.20 \times x \times$ & $1.64 *$ & .54 & Modal \\
\hline
\end{tabular}

Significant differences are indicated as follows: * means significant $(\mathrm{P}<0.05)$, ${ }^{\mathrm{xx}}$ means highly sigmificant $(\mathrm{P}<0.01)$, ${ }^{\mathrm{x} x}$ means very highly signifieant $(\mathrm{P}<0.001)$. 
of vine, width of vine, and amount of flowering were noted. When plants were 4 months old, the amount of flowering was noted again, the vines were removed and weighed, and rooting of runners was observed. Results were subjected to analysis of variance and regression techniques.

\section{RESULTS AND DISCUSSION}

Table 2 presents the results of the analysis of variance for 11 characteristics of 4 clones for 12 monthly planting dates. These show significant differences associated with months in 10 of the characteristics, with clones in all of the characteristics, and with month and clone interactions in 9 of the characteristics. Blocks (replication) were significanly different in only one characteristic. Figure 1 shows the distribution of the characteristics over 12 months.

Survival of cuttings, whether measured at 2 weeks or 4 weeks, was lowest following planting in December and February, months which corresponded to part of the dry season, but rate of survival was normal following planting in January and March, also dry months. Clones differed in this respect, and replications (blocks) also varied. Signifieant differences in water availability or in quality of the cuttings, a variable difficult to control, may be responsible for the observed differences.

Although cultivars differed in leaf lobing, lobing was not affected by season of planting. Clones differed in internode length, vine length, and plant width. In addition, month of planting affected each of these characteristics, and their distributions over 12 months were modal. Internodes were longer, vines were longer, and plants were wider in plantings made during the months of June to September, which correspond to the early part of the rainy season. However, as days became shorter, even during the rainy season (October to November), and during the dry season of short days (December to March), measurements of these characteristics decreased.

Vines of sweet potatoes tend to root at the nodes of the stem, and these roots sometimes tuberize. Clones differed in this respect. Although differences occurred according to months of planting, the distribution appeared bimodal and a clear relation to rainy season or day length was not seen. Similarly, with respect to tuberization of such roots, differences among months were marked, but could not be related to season or day length. Vine weights at harvest were highest in plantings made near the end of the dry season that matured during the rainy season.

Flowering response was complex. In general, flowering began when plants were 2 to 3 months old and was usually over by the fourth month, when vines were maturing. There were monthly and clonal differences as well as interactions among clones and months at 2 months and at 4 months after planting. Two clones, "Gem" and "SPT-8," were practically day neutral, for they usually flowered 2 months after planting 

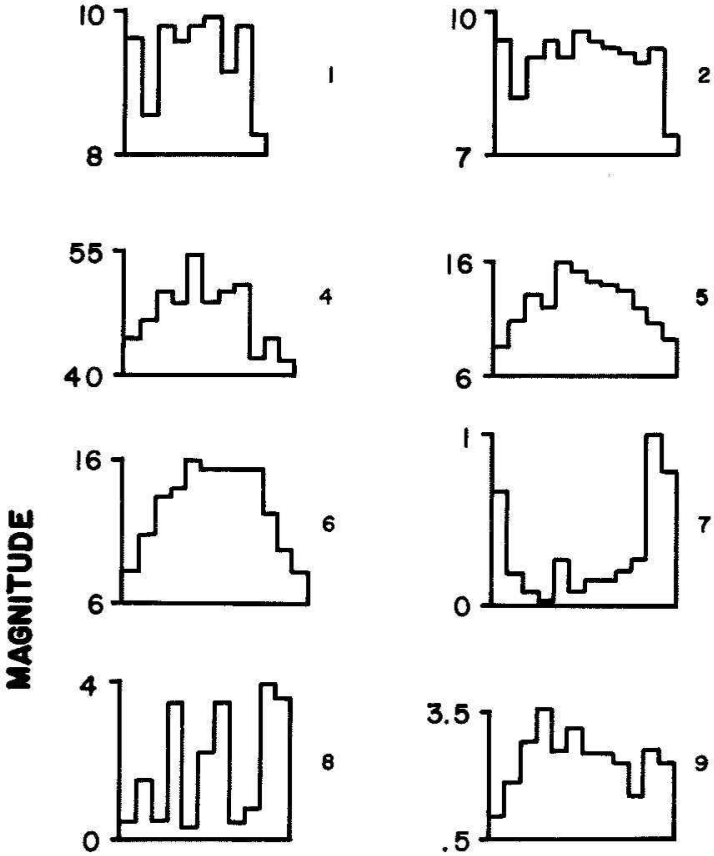

8
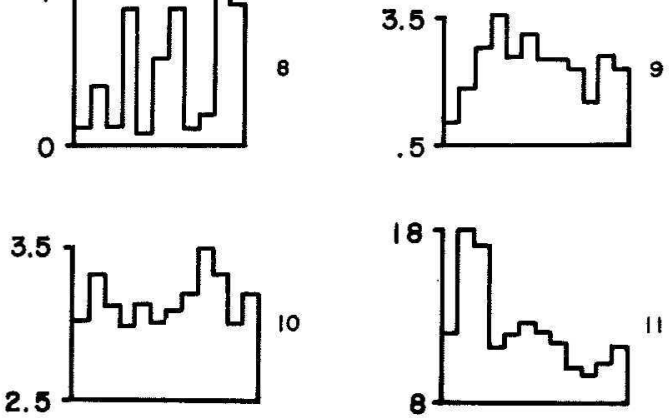

\section{MONTHS}

FIG. 1.-Monthly distributions of 10 characteristies measured in sweet potato plantings:

1. Survival of cuttings at 2 weeks. 2. Survival, 4 weeks. 3. Internode length. 4 . Vine length.

5. Plant width. 6. Flowering at 2 months. 7. Flowering at 4 months, 8 . Rooting of stem.

9. Thererization of such roets 10 Weicht of vines. 
TABLE 3.-Influenee of date of planting on flowering response of 4 sweet potato clones

\begin{tabular}{|c|c|c|c|c|c|c|c|c|}
\hline \multirow[b]{3}{*}{ Month of planting } & \multicolumn{8}{|c|}{ Degree of flowering ${ }^{1}$} \\
\hline & \multicolumn{2}{|c|}{ Gem } & \multicolumn{2}{|c|}{ Miguela } & \multicolumn{2}{|c|}{ SPT-8 } & \multicolumn{2}{|c|}{ SPV-46 } \\
\hline & $2^{2}$ & 4 & 2 & 4 & 2 & 4 & 2 & 4 \\
\hline January & 1.0 & 1.0 & 3.5 & 5.0 & 1.0 & 1.0 & 1.0 & 1.0 \\
\hline February & 1.5 & 5.0 & 1.5 & 5.0 & 1.5 & 5.0 & 1.0 & 1.0 \\
\hline March & 1.0 & 1.0 & 1.0 & 1.0 & 1.2 & 1.8 & 1.2 & 5.0 \\
\hline April & 1.0 & 1.0 & 1.0 & 1.0 & 1.0 & 1.0 & 1.0 & 1.0 \\
\hline May & 1.5 & 5.0 & 1.0 & 2.0 & 3.0 & 1.0 & 1.0 & 1.0 \\
\hline June: & 1.0 & 1.0 & 1.0 & 1.0 & 1.5 & 5.0 & 1.0 & 1.0 \\
\hline July & 1.0 & 5.0 & 1.0 & 1.2 & 1.5 & 4.8 & 1.0 & 1.2 \\
\hline August & 1.0 & 5.0 & 1.0 & 2.2 & 1.8 & 5.0 & 1.0 & 1.0 \\
\hline September & 1.0 & 1.0 & 1.0 & 1.0 & 2.0 & 5.0 & 1.0 & 1.0 \\
\hline Oetober & 1.5 & 5.0 & 1.0 & 1.2 & 2.0 & 5.0 & 1.0 & 1.0 \\
\hline November & 1.8 & 4.5 & 2.2 & 2.0 & 4.2 & 5.0 & 1.0 & 0.0 \\
\hline December & 1.0 & 1.0 & 1.0 & 1.0 & 1.0 & 3.0 & 1.0 & 1.0 \\
\hline
\end{tabular}

${ }^{1}$ Flowering response as: 1 . Not flowering; 2 , buds present; 3 . actively flowering; 4 , late flowering; 5 . post-flowering.

${ }^{2}$ Months after planting.

(table 3). The other two clones produced a few flowers only during the months with shorter days. Thus, the distribution of flowering response at 2 months was modal, but at 4 months was complex and difficult to interpret (fig. 1).

Table 4 shows the types of regressions between each characteristic and the 12 calendar months. For the majority of the characteristics there was no significant regression; thus, the months of the year, when arranged in a linear (chronological) fashion, are not related to the observed monthly differences. For some traits a linear, quadratic, or cubic regression is seen. The quadratic and cubic regressions of some traits, notably associated with growth of the foliage, are affected by season (rainfall, day length, and possibly temperature).

The sweet potato is a crop in which the annual cycle of growth has been distorted and masked by methods of cultivation. Seasonal ehanges in day length, rainfall, and temperature definitely affect the growth pattern. Nevertheless, sweet potatoes ean and are produced throughout the year in the tropics. Seasonal effects on morphological or growth characteristics caused the observed differences:

Short days led to poor vegetative growth and increased flowering; heavy rainfall encouraged vegetative growth, high temperatures accelerated growth processes, and excess cloudiness reduced net photosynthetic production. Thus, the effects of season are complex. These factors have been described by other investigators, but in this study it is obvious that each variety responds differently to ambient conditions. 
TABLE 4,-Regression of 11 sweet potato characteristics on month of planting

\begin{tabular}{|c|c|c|c|}
\hline No. & Characteristic & $\begin{array}{l}\text { Kind of } \\
\text { tegression }\end{array}$ & Interpretation \\
\hline 1 & Survival at 2 weeks & None & No regression on months \\
\hline 2 & Survival at 4 weeks & None or linear & No regression on months \\
\hline 3 & Leaf lobing & None & Season does not affect leaf type \\
\hline 4 & Length of internode & Quadratic & $\begin{array}{l}\text { Possibly affected by } 2 \text { seasonal } \\
\text { factors, rainfall and day length }\end{array}$ \\
\hline 5 & Length of vine & Cubie & $\begin{array}{l}\text { Possibly affected by } 2 \text { seasonal } \\
\text { factors, rainfall and day length }\end{array}$ \\
\hline 6 & Width of vine & Cubic & $\begin{array}{l}\text { Possibly affected by } 2 \text { seasonal } \\
\text { factors, rainfall and day length }\end{array}$ \\
\hline 7 & Flowering at 2 months & None or quadratic & $\begin{array}{l}\text { Short days might stimulate flowering } \\
\text { of young plants }\end{array}$ \\
\hline 8 & Flowering at 4 months & None & $\begin{array}{l}\text { Effects of short days on flowering } \\
\text { are short lived, and other factors } \\
\text { become important }\end{array}$ \\
\hline 9 & Rooting of stem & None & No regression on months \\
\hline 10 & Tubers along stem & None or cubic & No regression on months \\
\hline 11 & Weight of vine & Cubic & $\begin{array}{l}\text { Possibly affected by } 2 \text { seasonal } \\
\text { factors, rainfall and day length }\end{array}$ \\
\hline
\end{tabular}

Growth is affected by other factors as well as the seasons. These can include culture, especially condition of planting material, availability of water, weed growth, and fertilization. Whereas in this experiment an attempt was made to standardize all cultural treatments, seasonal effects interacted with cultural effects. Furthermore, it is now obvious that subtle differences in the planting material (5) and in pre- and post-planting treatments of such material can result in big differences in growth rate.

\section{LITERATURE CITED}

1. Badillo-Feliciano, J., 1976. Fffect of planting season on yield of sweet potato cultivars. J. Agric. Univ, P, R. 60: 163-71.

2. Gollifer, D. E., 1980. A time of planting trial with sweet potatoes. Trop. Agric. (Trinidad) 57:368-67.

3. Haynes, P. H., J. A. Spence and C. J. Walter, 1967. The use of physiological studies in the agronomy of root crops. Proc. Int. Symp. Trop. Root Crops, Trinidad. Sect. III, 1-17.

4. Mannan, M. A. and M. M. Rashid, 1984. Seasonal effects on the pattern of growth, tuberization, and root quality of sweet potato. Bangladesh $J$. Agric. Res. 9 (2): 89-96.

5. Martin, F. W., 1984. Effect of age of planting on yields of sweet potato from cuttings. Root and Tuber Crops Newsletter 15: 22-25.

6. MeDavid, C. R. and S. Alamu, 1980. Effect of daylength on the growth and development of whole plants and rooted leaves of sweet potato (Ipomoea batatas). Trop. Agric. (Trinidad) 57: 113-19. 